\title{
Proceedings of 2017 International Conference on Computer Science and Artificial Intelligence
}

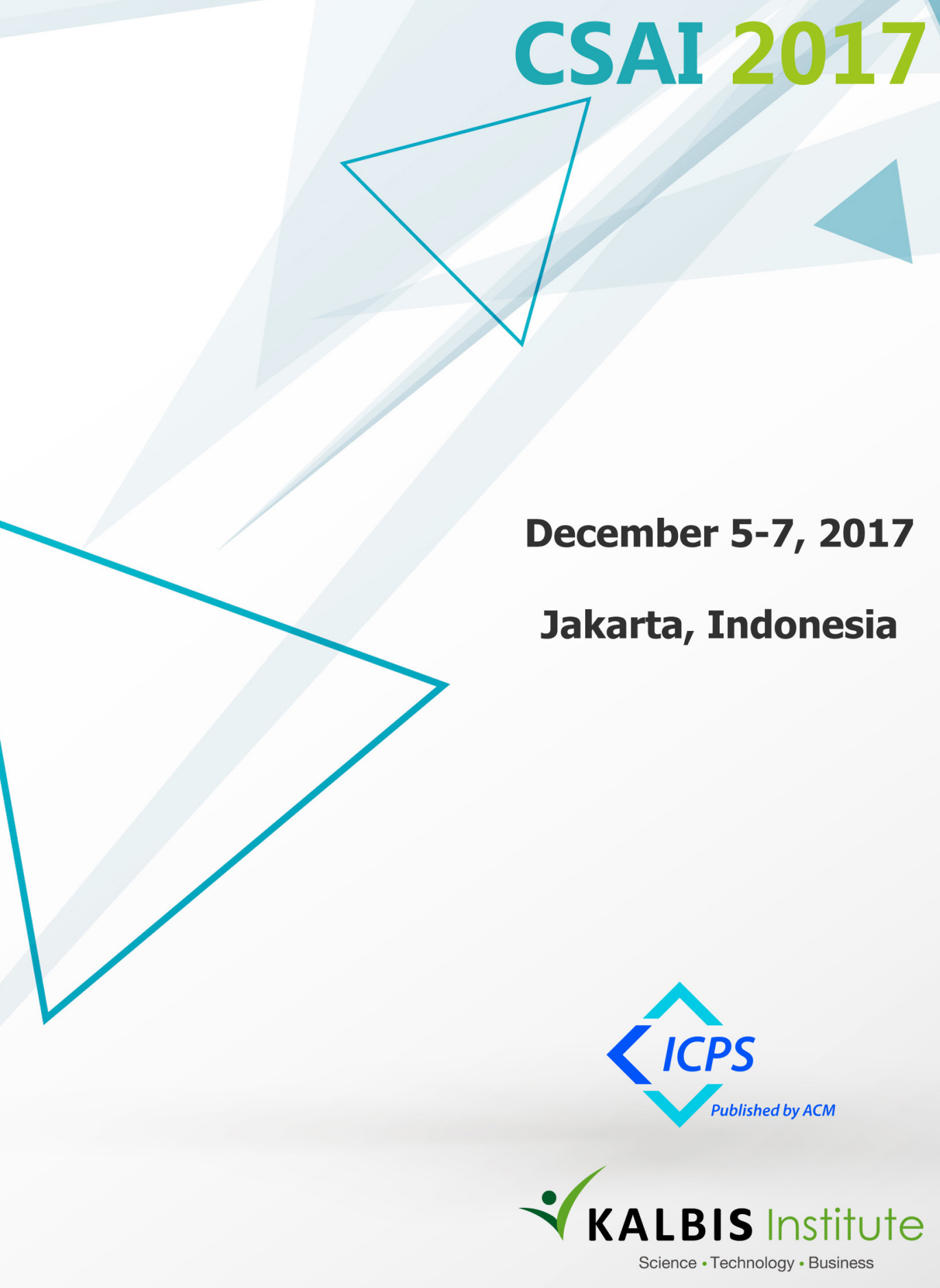




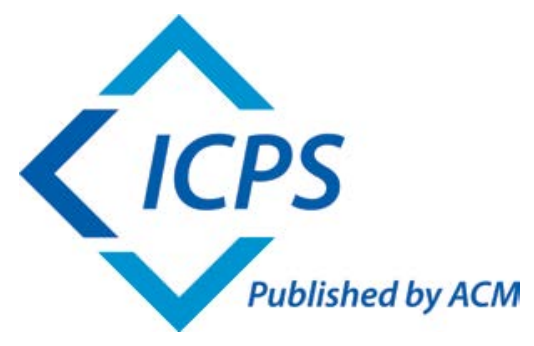

The Association for Computing Machinery

2 Penn Plaza, Suite 701

New York 10121-0701

ACM COPYRIGHT NOTICE. Copyright $(2017$ by the Association for Computing Machinery, Inc. Permission to make digital or hard copies of part or all of this work for personal or classroom use is granted without fee provided that copies are not made or distributed for profit or commercial advantage and that copies bear this notice and the full citation on the first page. Copyrights for components of this work owned by others than ACM must be honored. Abstracting with credit is permitted. To copy otherwise, to republish, to post on servers, or to redistribute to lists, requires prior specific permission and/or a fee. Request permissions from Publications Dept., ACM, Inc., fax +1 (212) 869-0481, or permissions@acm.org.

For other copying of articles that carry a code at the bottom of the first or last page, copying is permitted provided that the per-copy fee indicated in the code is paid through the Copyright Clearance Center, 222 Rosewood Drive, Danvers, MA 01923, +1-978-750-8400, +1-978-750-4470 (fax).

ACM ISBN: 978-1-4503-5392-2 


\title{
2017 International Conference on Computer Science and Artificial Intelligence
}

\author{
CSAI 2017
}

\section{Table of Contents}

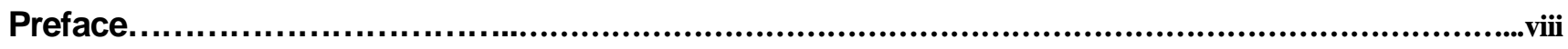

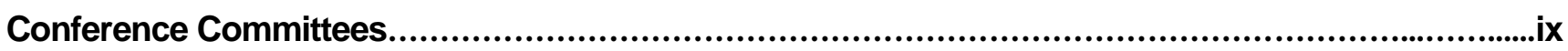

\section{Machine Learning and Artificial Intelligence}

Self-Augmenting Strategy for Reinforcement Learning 1

Xin Huang and Shuangjiu Xiao

A Bio-Inspired Approach to Infer Functional Rules and Aesthetic Goals from Music Genre Styles

Roberto De Prisco, Delfina Malandrino, Gianluca Zaccagnino, Rocco Zaccagnino and Rosalba Zizza

Face Recognition for Intelligent Robot Safety Verification System

Xingqian Li, Haoyu Zhao, Hongwei Zhao, Jianjun Wang and Peijun Xia

Local Search with Configuration Checking for PBS.

Ridong Han, Jianjun Wang and Xingqian Li

Augmented Reality Interaction on Property Developer Using User Centered Design Approach

Budi Arifitama, Ade Syahputra and Silvester Dian Handy Permana

Understanding Subjective Aspects in the Use of Human Computer Interface for Government Information

Systems: A Reflexive Analysis

Nayeth I. Solorzano Alcivar, Luke Houghton and Louis Sanzogni

Disambiguation of Homograms in a Pitch Accent Language. 32

Lucia Nacinovic Prskalo and Marija Brkic Bakaric 


\section{Software Design and Program Development}

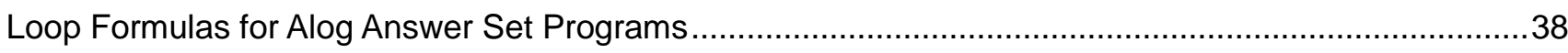

Cuixia Li, Yisong Wang*, Renyan Feng and Qianqian Li

AR Plants: Herbal Plant Mobile Application utilizing Augmented Reality

43

Jean M. Angeles, Fredilyn B. Calanda, Tony Vic V. Bayon-on, Roselia C. Morco, Junnel Avestro and Mark Jade S. Corpuz

e-RICE: An Expert System using Rule-Based Algorithm to Detect, Diagnose, and Prescribe Control Options for Rice Plant Diseases in the Philippines

Roselia C. Morco, Fredilyn B. Calanda, Jonathan A. Bonilla, Mark Jade S. Corpuz, Junnel E. Avestro and Jean M. Angeles

Development of a Generator for the Research View: Research Information Relation Visualization System .55

Takuma Oura, Koichi Anada, Takeo Yaku, Yasuhiko Morimoto, Shoichi Nakamura and Youzou

Miyadera

The Development Framework of Expert System Application on Indonesian Governmental Accounting System

Adhi Alfian

House Design Flood and Earthquake Resistant Recommender Application implementing Case-Base Content Filtering Algorithm

Junnel E. Avestro, Mark Jade S. Corpuz, Roselia C. Morco, Jean M Angeles, Fredilyn B. Calanda, John Paul S. Jasmin

\section{Image Analysis and Processing}

Native Patterns Identification using Hyperrectangles

Wladyslaw Homenda and Agnieszka Jastrzebska

Image Segmentation for One Way Video Traffic Using Background Substraction Method 76

Martinus Maslim, B. Yudi Dwiandiyanta and Jourgi Epardi

Determining Pigs Breeding Time by Sow's Vagina Image Analysis Using Wavelet Transforms and Artificial Neural Network

B. Yudi Dwiandiyanta, Ernawati and Martinus Maslim

Land Surface Deformation Mapping Method using PS-InSAR on ALOS/PALSAR Data in Bandung Region

Dodi Sudiana, Antoni, Rokhmatuloh and Josaphat Tetuko Sri Sumantyo 
FFT Algorithm of Complex Exponent Moments and Multi-distorted Invariance Analysis

YuWu

Covisance: A Real Time Mobile Recolorization Tool for Aiding Color Vision Deficient Users Utilizing D-15

Color Arrangement Test

Gerald R. Tecson, Fredilyn B. Calanda, Gerald T. Cayabyab and Felizardo C. Reyes Jr. Implementation of Image Fusion Method for Watermark on Color Image Using Wavelet Transformation Domain 100

Agung Mulyo Widodo and Budi Tjahjon

A Novel Three-phase Approach for Highly Corrupted Color Images 109

Ling Zhong, Yonghui Huang and Xiangqian Xiao

Implementation of Inner Product to Analyze Digital Handwriting based on Texture Traits 114

R. Davin RP., Dian Pratiwi, Syaifudin, Trubus R. and Rizky D.L.P.

\section{Design and Application of Information System}

Parallel Processing Design of Latent Semantic Analysis Based Essay Grading System with OpenMP

Anak Agung Putri Ratna, Ihsan Ibrahim and Prima Dewi Purnamasari

Combination of Dimensionality Reduction and User Clustering for Collaborative-Filtering 125

Ngo Tung Son, Dao Huy Dat, Nguyen Quang Trung and Bui Ngoc Anh

Maximizing Reliability of Heterogeneous Distributed System Using Bio-Inspired Technique for Task Allocation Problem

Farid Abbache and Hamoudi Kalla

Code Recommendation with Natural Language Tags and Other Heterogeneous Data 137

Fengyu Qiu, Weiyi Ge and Xinyu Dai

The Model of Elementary School Teachers Placement in Magelang District by Using Genetic Algorithm

Haris Sriwindono, Paulina H. Prima Rosa, Agnes Maria Polina and Robertus Adi Nugroho Developing Electronic Medical Record Based on NFC 148

Noor Cholis Basjaruddin, Edi Rakhman, Kuspriyanto and Mikhael Bagus Renardi eRheumatologist: Mobile-based Expert System for Rheumatology Utilizing Fuzzy Logic Algorithm 153

Mark Jade S. Corpuz, Junnel Avestro, Fredilyn B. Calanda, Roselia C. Morco, Jean M. Angeles and Carl Matthew S. Alcala 
Multimedia-Based Global Warming Interactive Application for Elementary School Students

Ken Widjaja and Hadi Sutopo

Comparisons of Tidal Prediction Analysis by Using Adaptive Neuro Fuzzy Inference System (ANFIS) and Artificial Neural Network (ANN)

Andy Hendri, S.T. M.T., Dr. Imam Suprayogi, S.T.M.T., Muhamad Zulfakar and Andarsin Ongko

Strategic Barriers in the Effective Integration of ICT in the Public Schools of Pakistan 169

Shafaq Salam, Zeng Jianqiu, Zulfiqar Hussain Pathan and Wang Lei

\section{Communication System and Network Security}

Neighbor-Passive Monitoring Technique for Detecting Sinkhole Attacks in RPL Networks

Mahmood Alzubaidi, Mohammed Anbar and Sabri M. Hanshi

Performance Comparison of MANET Routing Protocol based on RandomWaypoint Mobility Model

Bekti Maryuni Susanto, Agus Hariyanto and Surateno

Improved Method of Aperiodic Spread Spectrum Acquisition

Siqi Ma, Celun Liu and Jia Wang

Carrier Synchronization Based on Maximum Likelihood Criterion under High Dynamic

Jia Wang, Celun liu and Siqi Ma

An Integrated Real-Time Simulated Ethical Hacking Toolkit with Interactive Gamification Capabilities and

Cyber Security Educational Platform 199

Vimalnath N. Mathoosoothenen, Jakanath S. Sundaram, Ram A. Palanichamy and Sarfraz N. Brohi Negation of Ransomware via Gamification and Enforcement of Standards 203

Yap L. Dion, Abigail A. Joshua and Sarfraz N. Brohi

Website Based Registration and Payment Information Systems at Primadia Clinic Laboratory 209

Paul Clinton Pitoy and Mira Ziveria

Survey of Privacy Enabling Strategies in IoT Networks. 216

Lukáš Hellebrandt, Ondřej Hujňák, Petr Hanáček and Ivan Homoliak

A Conceptual Security Approach with Awareness Strategy and Implementation Policy to Eliminate Ransomware 222

Jordan W. Han, Ong J. Hoe, Joseph S. Wing and Sarfraz N. Brohi 
Analyzation of Relationships among Search Queries for Extracting the Complicated Contexts in Web Exploration.

Shoichi Nakamura, Takuya Matsumoto, Hiroki Nakayama, Ryo Onuma, Hiroaki Kaminaga and Youzou Miyadera

\section{Computer Theory and Engineering Technology}

The Analysis of Traffic Drivers' Behavior based on Kmeans

Xianmei Lang, Zairang Zhao and Guixi Xiong

Failure Cause Extraction of Railway Switches Based on Text Mining.....

Chunni Lin and Guang Wang*

L2D: A Modified Algorithm based on Edit Distance for Searching Thai-English Transliterated Words ....242 Kitsiri Chochiang

Customer Oder Fulfillment Process Analysis with Process Mining: An Industrial Application in a Heavy Manufacturing Company

Hind R'bigui and Chiwoon Cho

Quality Mapping of Senior High Schools Based On National Exam Scores and Absorption Level: A Case

Study at Special Region of Yogyakarta 253

Paulina H. Prima Rosa and Ignatius Aris Dwiatmoko

Practical Method of Low-Light-Level Binocular Ranging Based on Triangulation and Error Correction

Qi Shi, Lei Ma and Yiping Yang

Measurement Metric Proposed For Big Data Analytics System

Ridha Sefina Samosir, Harco Leslie Hendric, Ford Lumban Gaol, Edi Abdurachman and Benfano

Soewito

Infant Body Temperature Monitoring System using Temperature Change Detection Algorithm

Tae-HunWoo, Hwa-Ju Jo, Yong-Hwan Lee and Sung-Young Kim*

Wind Power Prediction by Using Wavelet Decomposition Mode Based NARX-Neural Network

A.Prasetyowati, H.Sudibyo and D.Sudiana

Design of Driving Simulator Using PID and Bidirectional Communication Control System

Claudia Cahya Primadani, Neola Layalia Rahmah, Hajar Fadliastuti and Agus Virgono Impulse Of Triangle and Square Wave With TENS Methode Based On Microcontroller 285

Wisnu Broto, Noor Suryaningsih, Fauzie Busalim, Ane Prasetyowati 


\section{Preface}

2017 International Conference on Computer Science and Artificial Intelligence (CSAI 2017) was held in Jakarta, Indonesia during December 5-7, 2017. The purpose of CSAI is to bring together researchers and people from industry working in the fields of computer science and artificial intelligence. It seeks to offer a broad spectrum of current research in this area of theoretical and applied knowledge.

The volume consists of 53 selected papers (from originally 94 papers) which are presented orally at the conference or via poster session. The topics of papers include machine learning and artificial intelligence, software design and program development, image analysis and processing, design and application of information system, communication system and network security as well as computer theory and engineering technology.

The papers are accepted after being peer-reviewed by the conference Technical Program Committee and international reviewers based on the topic of each paper. All the authors of accepted papers have done excellent presentations on this conference via oral presentation or poster presentation. On the basis of the conference achievement, we collect and compile these research papers into the conference proceedings, in which the content represents the latest international academic progress of computer science and artificial intelligence fields. We hope that the presented papers will be interesting for readers and be a good base for inspiration for future developments.

The chairpersons, keynote speakers, plenary speaker played important role in conducting the proceedings of the session in a timely and efficient manner and on behalf of the conference committee, we express sincere appreciation for their involvement. The reviewers of the manuscripts, those by tradition would remain anonymous, have also been very helpful in efficiently reviewing the manuscripts, providing valuable comments well within the time allotted to them. We express our sincere and grateful thanks to all reviewers.

We truly believe the participants will find the discussion fruitful, and will enjoy the opportunity for setting up future collaborations. It is our sincere hope that CSAI will one day become the leading conference in this specific academic area.

CSAI 2017 Organizing Committee

December 22, 2017 


\section{Committees}

\section{Conference Chairs}

Prof. Nabil EL Kadhi, University of Buraimi, Sultunate of Oman

Prof. Hossein Sarrafzadeh, Unitec Institute of Technology, New Zealand

Dr. Hadi Sutopo, Dean, Kalbis Institute, Indonesia

\section{Technical Program Committee Chairs}

Assoc. Prof. Dr. Eko K. Budiardjo, University of Indonesia, Indonesia

Prof. Dr. Ir. Eko Sudiyono, Universitas Kristen Satya Wacana, Indonesia

Prof. Dr. Ir. Maria Angela Kartawidjaja, Universitas Katolik Indonesia Atma Jaya, Indonesia

Prof. Shihab A. Hameed, International Islamic University Malaysia, Malaysia

\section{Local Organizing Committee}

Dr. Hadi Sutopo, Dean, Kalbis Institute, Indonesia

Yulius Denny Prabowo, Kalbis Institute, Indonesia

Anjar Dwi Astono, Kalbis Institute, Indonesia

Jullend Gatz, Kalbis Institute, Indonesia

\section{Technical Committee}

Prof. Dr. M. Surendra Prasad Babu, Andhra University, India

Assoc. Prof. Dr. Djoko Budianto S, Universitas Atma Jaya Yogyakarta, Indonesia

Dr. Ir. Paulus Insap Santosa, Universitas Gajah Mada, Indonesia

Dr. Fuhua (Oscar) Lin, Athabasca University Alberta, Canada

Dr. KokSheik Wong, Monash University Malaysia, Malaysia

Dr. Lipur Sugiyanta, Universitas Negeri Jakarta, Indonesia

Dr. Evizal Abdul Kadir, Universitas Islam Riau, Indonesia

Dr. M. Jamal Deen, McMaster University, Canada

Dr. Sayyed Majid Mazinani, Imam Reza University, Iran

Prof. Dr. N. Ch. Sriman Narayana Iyengar, VIT University, India

Prof. Arivazhagan N, VIT University, India 
Prof. \& Dean. Jayantrao Bhaurao Patil, R C Patel Institute of Technology, India

Asst. Prof. Kedar Valmik Kekan, BITS Pilani India

Assoc. Prof. Shamim Ripon, East West University, Bangladesh

Dr. M.V. Siva Prasad, Anurag Engineering College, India

Asst. Prof. Atila Bostan, ATILIM UNIVERSITY, Turkey

Prof. Syed Akhter Hossain, Daffodil International University, Bangladesh

Asst. Prof. Imran Usman, Saudi Electronic University, Saudi Arabia

Prof. Dr. Abdurazzag Ali Aburas, University of KwaZulu-Natal, South Africa

Dr. Jeril Kuriakose, Manipal University Jaipur, India

Assoc. Prof. Lin Lanfen, Zhejiang University, China

Lecturer. Sarfraz Brohi, Taylor's University, Malaysia

Assoc. Prof. Anak Agung Putri Ratna, Universitas Indonesia, Indonesia

Lecturer Prima Dewi Purnamasari, Universitas Indonesia, Indonesia

Lecturer Silvester Dian Handy Permana, Universitas Trilogi, Indonesia

Lecturer Akeem Olowolayemo, University Malaysia Sarawak, Malaysia

Lecturer Bekti Maryuni Susanto, POLIJE, Indonesia

Lecturer Surateno Surateno, POLIJE, Indonesia

Asst. Prof. Agnieszka Jastrzebska, Warsaw University of Technology, Poland

Lecturer Budi Arifitama, Universitas Trilogi, Indonesia

Prof. Chiwoon Cho, University of Ulsan, Korea

Lecturer Agus Hariyanto, POLIJE, Indonesia

Assoc. Prof. Manuel Filipe Santos, University of Minho, Portugal

Asst. Prof. Gahangir Hossain, Texas A\&M University, Kingsville, USA

Prof. Jianqiu Zeng, Beijing University of Posts and Telecommunication, China

Assoc. Prof. Wladyslaw Homenda, Warsaw University of Technology, Warsaw, Poland

Asst. Prof. Hamoudi Kalla, University of batna, Algeria

Asst. Prof. Marija Brkic Bakaric, University of Rijeka, Croatia

Lecturer Filipe Portela, University of Minho, Portugal

Asst. Prof. Gerald Cayabyab, Technological Institute of the Philippines - Quezon City, Philippines

Asst. Prof. Fredilyn Calanda, Technological Institute of the Philippines - Quezon City, Philippines 
Asst. Prof. Felizardo Reyes Jr., Technological Institute of the Philippines - Quezon City, Philippines Asst. Prof. Michal Kruk, Warsaw University of Life Sciences, Poland Asst. Prof. Jaroslaw Kurek, Warsaw University of Life Sciences, Poland

Asst. Prof. Bartosz Swiderski, Warsaw University of Life Sciences, Poland 


\section{Determining Pigs Breeding Time by Sow's Vagina Image Analysis Using Wavelet Transforms and Artificial Neural Network}

\author{
B. Yudi Dwiandiyanta \\ Universitas Atma Jaya Yogyakarta \\ Jl. Babarsari No. 43 \\ Yogyakarta, 55281 \\ $+62274-487711$ \\ yudi-dwi@staff.uajy.ac.id
}

\author{
Ernawati \\ Universitas Atma Jaya Yogyakarta \\ Jl. Babarsari No. 43 \\ Yogyakarta, 55281 \\ +62274-487711 \\ ernawati@staff.uajy.ac.id
}

\author{
Martinus Maslim \\ Universitas Atma Jaya Yogyakarta \\ Jl. Babarsari No. 43 \\ Yogyakarta, 55281 \\ +62274-487711 \\ martinusmaslim@staff.uajy.ac.i
}

\begin{abstract}
A rapid development of image processing technique has been currently taking place. Image analysis is becoming an application which attracts a lot of attention among the other applications. It extracts image features to identify an object.Image analysis has been widely used in several fields such as animal husbandry.The object used in this study is the image of sow vagina. Determining the pig breeding time is something necessary for the breeders since it will greatly affect the number of piglets. The complexity in determining the pig breeding period becomes a main problem in this research. This system has been successfully established. The system can recognize patterns well with a maximum recognition rate of $98.7013 \%$. In general Haar wavelets, $\mathrm{db} 2$ and coif1 produce better recognition performance. Haar wavelets are wavelets that have fewer computational loads than others.
\end{abstract}

\section{CCS Concepts}

- Computing methodologies $\rightarrow$ Artificial intelligence $\rightarrow$ Computer vision $\rightarrow$ Computer vision problems $\rightarrow$ Object recognition.

\section{Keywords}

Image Analysis; Wavelet Transforms; Haar; daubechies; coiflets; artificial neural network.

\section{INTRODUCTION}

The development of image processing has currently been quite rapid. This is supported by the development of computers with large memory capacity therefore it is possible to perform computing in a relatively short time. There are many applications contained in image processing techniques, such as image enhancement, image restoration, image analysis, image

Permission to make digital or hard copies of all or part of this work for personal or classroom use is granted without fee provided that copies are not made or distributed for profit or commercial advantage and that copies bear this notice and the full citation on the first page. To copy otherwise, or republish, to post on servers or to redistribute to lists, requires prior specific permission and/or a fee.

CSAI 2017, December 5-7, 2017, Jakarta, Indonesia

(C) 2017 Association for Computing Machinery.

ACM ISBN 978-1-4503-5392-2/17/12 ..\$15.00

DOI: https://doi.org/10.1145/3168390.3168412 compression, and image data security systems [1]. The application which mostly attracts the attention among all of other applications is image analysis. It seeks to extract image features for identifying an object. Image analysis has been widely used in several fields.

This study discusses the application of image analysis in the field of animal husbandry. The object used in this research is the image of sow's vagina. Pig is a mammal which population is large and quite significant in Indonesia although it is less than cows and goats. It is due to not all regions in Indonesia can accept the existence of pig farms. Deciding the pig breeding time is necessary for breeders since it will greatly affect the number of piglets. Each boar can produce 200-250 cc of semen which contains 50-60 million sperm during mating. The fertilization occurred in sow needs only 100 cc sperms. However the sows are not all the time willing to mate with the boars. Only at certain moments alone can the sows are willing to mate with the boars.

The characteristics of a sow that is going to mate with a boar can be observed primarily on its vagina marked with red, swollen and mucus coming out. The observation done by human's sight is sometimes considered difficult to determine the exact mating times for the pigs since the pigs sometimes do not show the obvious signs. Pig breeding at inappropriate times will result either in failure on fertilization process or the number of piglets which do not match with what is expected.

The complexity in determining the pig breeding time period becomes a major problem in this study. Wavelet is then utilized as a preprocessing in the recognition of vagina image patterns. Wavelet is not only used as a new analytical device in mathematics but also a very reliable practical device for various applications ranging from differential equations to image processing. Wavelet and wavelet transformation are salient fields of computer graphics. Some applications that have been successfully created by utilizing wavelet are image compression, sound synthesis for music, image improvement, image edge detection, and so forth.

\section{LITERATUR REVIEW}

Image analysis is a part of image processing which extracts meaningful information from images. The analysis or the interpretation can be automatically generated by devices such as computer. Image analysis has been developed in various fields of science. At the classification of character recognition, image analysis can be used as sorting of mails, optical character recognition [2], and bank checks processing. In the medical field, 
image analysis is applied to the tumor detection process [3], measurement of the size and shape of internal organs [4], chromosome analysis [5], and red blood cells calculation. In the automotive industry, image analysis is used in the parts identification. In robotics, image analysis is used in the process of objects recognition and interpretation [6], and the robots movement control. In cartography, image analysis is used to synthesize weather maps. In forensics, image analysis can be used to match fingerprint [7] and to analyze automated securities systems. At the radar system, image analysis is used for target identification and detection, helicopter or aircraft landing assistance. Image analysis is also widely applied in remote sensing system for multispectral image analysis [8], weather forecasts [9], and agriculture industry from satellite image.

Based on its domain classification, there are two methods of performing image analysis. First is image analysis on spatial domain and the second is on frequency domain. The image analysis process is firstly developed solely in spatial domain. At the spatial image analysis process, an object features are only characterized by its gray level, joint-probability distribution, and spatial distribution. Some of the most commonly used methods are the decomposition of amplitude characteristics and the decrement of histogram characteristics. The superiority of image analysis in spatial areas is mainly due to relatively small computational load, but this method is very conventional and lacks the desired results [10].

Pattern recognition is a study to find out how machines observe the surrounding environment and learn the differences in object patterns and their background [11]. Pattern recognition becomes an interesting research topic of image processing as it brings potential benefits to various aspects of life. The pattern recognition is getting popular and widely used as a research topic

The pattern recognition in medical and the biometric identification are the evidence of how pattern recognition has greatly contributed on giving benefits for human life. The pattern recognition is utilized in medical to diagnose a disease and it is also used to observe the fetus growth in the womb. Dealing with internal organs is a complex job which has a high level of difficulty therefore the system is made use in order to establish a doctor's accurate diagnosis that may later decide the next medical treatment. The system is developed for giving the further information to the doctors in deciding the advanced medical treatment steps [12], [13], [14], [15].

This research is conducted to analyze the sow's genital image by using wavelet and artificial nerve tissue. The wavelet is functioned to reduce the image size and to segment the features of the object's image [16]. Artificial nerve tissue is used for the given object's image identification or recognition process. There are 2 phases in the identification process using artificial neural networks namely training phase and application phase. Color coordinate system to be used is the RGB color coordinate system and YUV. Both of their performances will be compared in order to obtain the best results according to the features and the characteristic of the object's image.

\section{METHODOLOGY}

The methodology adopted in this study is divided into five stages. The first stage is material collection. The materials are collected to obtain a complete literature of the current research topic. The collecting of materials is done by searching for books, journals, and theses which are related to the topic from library and the internet. The gathered relevant materials are used to develop the algorithm for the study. The second stage is data collection. The data are obtained directly from a pig farm at Sanggrahan village, Banyuraden, Gamping, Sleman, Yogyakarta. The data which are going to be acquired are the genital image of the sows which are not ready to breed and ready to breed. The data are taken from 30 sows. The obtained data are then cropped and resized in order to get the data in the forms of image color in .bmp format (Windows Bitmap) with $256 \times 256$ pixels. The third stage is software design. The algorithm based flowcharts is developed at this stage. This is intended to ease the software development. The fourth stage is software development. The flowchart design is then implemented using the Matlab2013 programming language. The final stage is software testing. The finished software is then tested using the real image data to find out whether the software has run as it is desired.

\section{DISCUSSION}

The first recognition algorithm test was performed on an 8-bit grayscale color coordinate space. The selection of grayscale color coordinates is based on the simplicity of the computational load. The system was piloted with 77 pieces of images with 2 main patterns, namely "pigs not ready to be mated" and "pigs ready to be mated". Examples of test images can be seen in Figures 1 and 2. Table 1 is the percentage of recognition with variations in the value of alpha, decalpha and wavelet training. In this test used wavelet type with a short filter and has orthonormal properties, so it is expected to suppress the computational load.
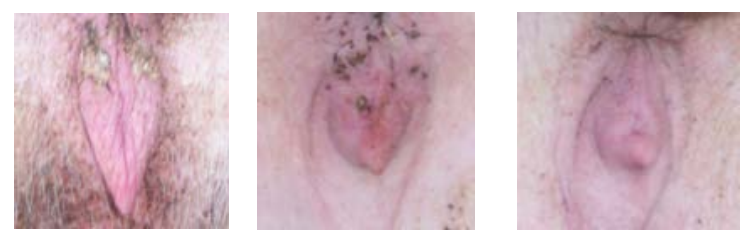

Figure 1. Example of pattern test image "Pig not ready to be mated"
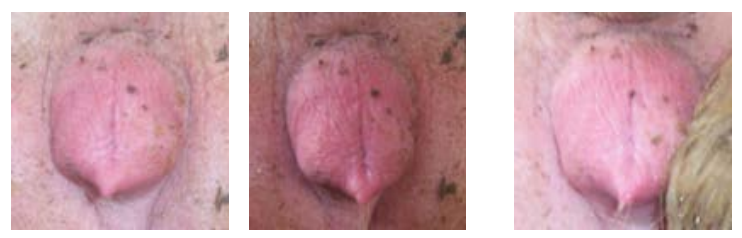

Figure 2. Example of pattern test image "Pig ready to be mated"

Figure 1 is an example of some test images of the sow's vagina image that are not ready for mated. Based on the physical characteristics it appears that vagina is not slimy and has a relatively bright color. Figure 2 is an example of some imagery image of sow's vagina image that is ready to be mated. Based on the observation of the physical characteristics seen that the genital red, swollen and out mucus. The computer software developed in this study should be able to distinguish the two patterns above. 
Table 1. The percentage of Recognition with variations in the value of alpha, decalfa and wavelet training.

\begin{tabular}{|c|c|c|c|c|c|c|}
\hline \multirow{2}{*}{ Alpha } & \multirow{2}{*}{ decAlpha } & \multirow{2}{*}{ Iteration } & \multicolumn{4}{|c|}{ Percentage of Recognition } \\
\hline & & & Haar & Db2 & db4 & Coif1 \\
\hline \multirow[t]{6}{*}{0.01} & 0.1 & 66 & 98.7013 & 96.1039 & 81.8182 & 96.1039 \\
\hline & 0.2 & 31 & 97.4026 & 98.7013 & 81.8182 & 98.7013 \\
\hline & 0.3 & 20 & 97.4026 & 98.7013 & 81.8182 & 97.4026 \\
\hline & 0.5 & 10 & 97.4026 & 97.4026 & 81.8182 & 96.1039 \\
\hline & 0.8 & 5 & 94.8052 & 97.4026 & 81.8182 & 94.8052 \\
\hline & 1 & 1 & 92.2078 & 97.4026 & 81.8182 & 94.8052 \\
\hline \multirow[t]{6}{*}{0.005} & 0.1 & 59 & 97.4026 & 98.7013 & 81.8182 & 98.7013 \\
\hline & 0.2 & 28 & 97.4026 & 97.4026 & 81.8182 & 96.1039 \\
\hline & 0.3 & 18 & 97.4026 & 97.4026 & 81.8182 & 94.8052 \\
\hline & 0.5 & 9 & 92.2078 & 97.4026 & 81.8182 & 94.8052 \\
\hline & 0.8 & 4 & 92.2078 & 97.4026 & 81.8182 & 94.8052 \\
\hline & 1 & 1 & 92.2078 & 97.4026 & 80.5195 & 94.8052 \\
\hline \multirow[t]{6}{*}{0.003} & 0.1 & 55 & 97.4026 & 98.7013 & 81.8182 & 96.1039 \\
\hline & 0.2 & 26 & 97.4026 & 97.4026 & 81.8182 & 94.8052 \\
\hline & 0.3 & 16 & 92.2078 & 97.4026 & 81.8182 & 94.8052 \\
\hline & 0.5 & 9 & 92.2078 & 97.4026 & 81.8182 & 94.8052 \\
\hline & 0.8 & 4 & 88.3117 & 96.1039 & 80.5195 & 94.8052 \\
\hline & 1 & 1 & 85.7143 & 96.1039 & 80.5195 & 96.1039 \\
\hline \multirow[t]{6}{*}{0.001} & 0.1 & 44 & 92.2078 & 97.4026 & 81.8182 & 94.8052 \\
\hline & 0.2 & 21 & 92.2078 & 97.4026 & 80.5195 & 94.8052 \\
\hline & 0.3 & 13 & 87.0130 & 96.1039 & 80.5195 & 94.8052 \\
\hline & 0.5 & 7 & 87.0130 & 96.1039 & 80.5195 & 94.8052 \\
\hline & 0.8 & 3 & 87.0130 & 93.5065 & 80.5195 & 90.9091 \\
\hline & 1 & 1 & 87.0130 & 93.5065 & 80.5195 & 92.2078 \\
\hline \multirow[t]{6}{*}{0.0001} & 0.1 & 22 & 87.0130 & 92.2078 & 80.5195 & 92.2078 \\
\hline & 0.2 & 11 & 87.0130 & 89.6104 & 80.5195 & 92.2078 \\
\hline & 0.3 & 7 & 87.0130 & 88.3117 & 80.5195 & 92.2078 \\
\hline & 0.5 & 4 & 87.0130 & 87.0130 & 80.5195 & 92.2078 \\
\hline & 0.8 & 2 & 87.0130 & 87.0130 & 80.5195 & 92.2078 \\
\hline & 1 & 1 & 87.0130 & 87.0130 & 80.5195 & 92.2078 \\
\hline
\end{tabular}

\subsection{Noise Effect on Introduction Algorithm}

Noise is the unwanted signals on the image. Usually these signals appear at the time of image digitization process. In digital imagery, noise is part of the digital image that affects the quality of the image. There are two types of noise, namely Gaussian noise and salt and pepper noise. In Gaussian the existing color noise at each noise point is different, the color value for this noise is the result of the reduction or addition of the pixel color values in the original image. While the noise salt and pepper is often known as impulse or shot noise. Noise on this type of shaped white spots and black scattered. Usually occurs due to data transmission errors and is not correlated at all with the neighboring pixels.

In this section, the algorithm will be tested with the effect of salt and pepper noise on the image to be recognized. Noise is given starting intensity $10 \%-100 \%$. Figure 3 below is an example of sow's vagina image that is given salt and pepper noise. It can be seen from the picture that giving noise with intensity more than $60 \%$ visually image pattern can no longer be recognized.
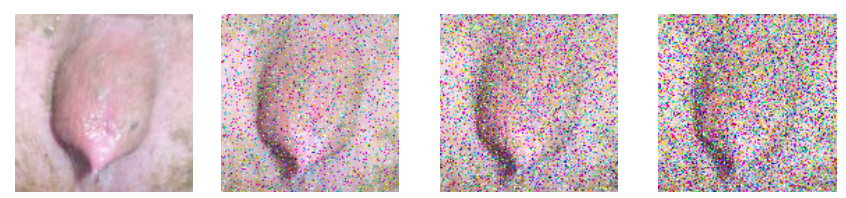

Figure 3. The "Pigs Ready Mated" Pattern Pattern Have Been Given Salt and Pepper Noise.

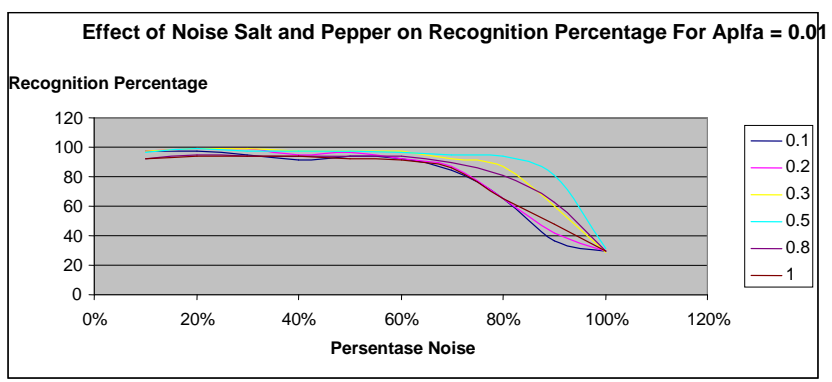

Figure 4. Graph of Effect of Noise Salt and Pepper on Recognition Percentage For Alfa $=0.01$ and DecAlfa Value Variation.

Based on the graph in Figure 4. it is seen that the presence of noise is very influential on the performance of the recognition algorithm. The greater the intensity of noise given, the smaller the percentage of recognition value generated by the system. The pattern recognition system developed can recognize the pattern well until the noise intensity level is $60 \%$. Visually observation with the eyes is very difficult to distinguish between two kinds of patterns when given noise more than $50 \%$. Noise in the day-today may occur when there is an interruption when recording an object, or there are obstacles that interfere with the recording process. 


\subsection{Computational Load Comparison}

The computational load will be calculated using the flops generated from the training process and the application process with input 77 test images. Table 2 is the flops comparison between recognition made in grayscale color coordinates, YUV and RGB color coordinates. Each color coordinate will be tested using Haar wavelet, db2, db4 and coif1.

Table 2. Flops Comparison

\begin{tabular}{|l|l|l|l|l|}
\hline & Haar & db2 & db4 & coif1 \\
\hline Grayscal & 1456857 & 2333868 & 41580133 & 3220698 \\
$\boldsymbol{e}$ & 66 & 80 & 8 & 15 \\
\hline YUV & 1533351 & 2410376 & 42345171 & 3297201 \\
& 08 & 47 & 9 & 63 \\
\hline RGB & 3909163 & 6540049 & $1.2012 \mathrm{e}+0$ & 9200256 \\
& 49 & 89 & 09 & 25 \\
\hline
\end{tabular}

Based on Table 2 it is seen that the largest computational load is found on pattern recognition in RGB color coordinate system. This is because pattern recognition in RGB color coordinate system will process the input image on three different color components. The computational load borne by processing in RGB color coordinates is approximately $3 \mathrm{x}$ the computational load in the grayscale color coordinate system. The type of wavelet also affects the resulting computational load. Haar wavelets are wavelets that have the least computation load, whereas wavelet $\mathrm{db} 4$ has the greatest computation load compared to other wavelets. The amount of computational load is strongly influenced by the length of the wavelet filter used.

\section{CONCLUSION}

The system for pig breeding has been successfully established. The system can recognize patterns well with a maximum recognition rate of $98.7013 \%$. The system can be used to help pig farmers in determining the mating period for their livestock.

Haar wavelets are wavelets that have fewer computational loads than others. While wavelet db4 has the largest computational load. Haar wavelets have relatively fewer computational loads because they have short filter lengths. Wavelet $\mathrm{db} 4$ has a large computational load because wavelet $\mathrm{db} 4$ has a relatively long filter length. In general Haar wavelets, db2 and coif1 produce better recognition performance. While wavelet $\mathrm{db} 4$ less suitable for this research.

\section{ACKNOWLEDGMENTS}

Our thanks to ACM SIGCHI for allowing us to modify templates they had developed.

\section{REFERENCES}

[1] Gonzales, R., 2007., Digital Image Processing, Pearson, 3rd edition.

[2] Shrivastav, Jitendra; Gupta, Ravindra Kumar; Singh, Shailendra, 2013, A Modified Back propagation Algorithm for Optical Character Recognition, COMPUSOFT, An International Journal of Advanced Computer Technology, 2(6), pp. 180-184.

[3] Olaleke J. O., Adetunmbi A. O., Obe O. O. and Iroju O. G., 2015, Automated Detection of Breast Cancer's Indicators in
Mammogram via Image Processing Techniques, British Journal of Applied Science \& Technology, 9(1), pp. 53-64

[4] Hammad, Seddik, 2014, Protocols For Staining Of Bile Canalicular and Sinusoidal Networks of Human, Mouse and Pig Livers, Three Dimensional Reconstruction and Quantification of Tissue Microarchitecture by Image Processing and Analysis, Arch Toxicol, 88, pp. 1161-1183

[5] Burnside R.D., Spudich L, Rush B, Kubendran S, Schaefer G.B., 2013. Secondary Complex Chromosome

Rearrangement Identified by Chromosome Analysis and FISH Subsequent to Detection of an Unbalanced Derivative Chromosome 12 by SNP Array Analysis. Cytogenet Genome Res 2014;142: pp. 129-133

[6] Agrawal, Akash; Brijpuria Palak, 2015, A Dynamic Object Identification Protocol for Intelligent Robotic Systems, I.J. Image, Graphics and Signal Processing, 2015, 8, pp. 35-41

[7] Thaiyalnayaki, K.; Karim, S. Syed Abdul; Parmar, P. Varsha, 2010, Finger Print Recognition using Discrete Wavelet Transform, International Journal of Computer Applications (0975 - 8887) Volume, 1(24), pp. 82-85.

[8] Teo, Tee-Ann and Lau Chi-Chung, 2012, Pyramid-based Image Empirical Mode Decomposition for The Fusion of Multispectral and Panchromatic Images, Journal on Advances in Signal Processing, 2012 (4), pp 1-12

[9] Delgado, Germán; de Valk, Paul; Redaño, Ángel; van der Veen, Sibbo; Lorente, Jerónimo, 2008, Verification of an MSG Image Forecast Model: METCAST, Weather and Forecasting, 23(4), pp. 712-724.

[10] Jain, A.K., 1995, Fundamentals of Digital Image Processing, Prentice Hall of India, New Delhi, India.

[11] Basu, J.K., Bhattacharyya, D. \& Kim, T., 2010. Use of Artificial Neural Network in Pattern Recognition. International Journal of Software Engineering and Its Applications, 4(2), pp.23-34.

[12] Gurgaon, 2013. Computer Aided Diagnosis Based on Medical Image Processing and Artificial Intelligence Methods. International Journal of Information and Computation Technology, 3(9), pp.887-92.

[13] Bhulyan, A.H., Azad, I. \& Uddin, K., 2013. Image Processing for Skin Cancer Features Extraction. International Journal of Scientific \& Engineering Research, 4(2), pp.1-6.

[14] Patil, S.A. \& Kuchnaur, M.B., 2008. Lung Cancer Classification Using Image Processing. International Journal of Engineering and Innovative Technology (IJEAT), 2(3), pp.37-42.

[15] [Nagaraj, S., Rao, G.N. \& Koteswararao, K., 2010. The Role of Pattern Recognition in Computer Aided Diagnosis and Computer Aided Detection in Medical Imaging a Clinical Validation. International Journal of Computer Application, 8(5), pp.18-22.

[16] Chui, C. K., 1997, Wavelets: A Mathematical Tool for Signal Analysis, SIAM. 